\title{
Finding nature \& sanctuary in the city
}

Marjorie Jacobs, MA

Neurolog $y^{\circledR}$ 2018;91:1105-1106. doi:10.1212/WNL.0000000000006657

Figure Fagus grandifolia city sanctuary

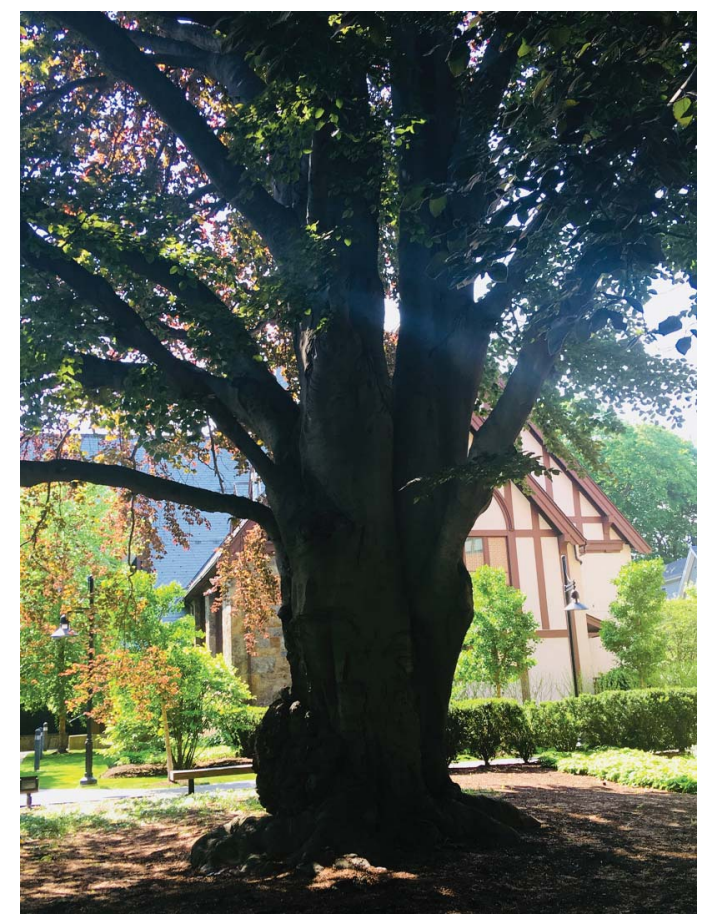

We move in silence

a small community practicing

slow walking

around jeweled side streets

we don't usually see

no two houses the same-

stone, stucco, brick, clapboard-

each ringed in green, coiffured

flanked by a 2-car garage.

We have passed by them many times

blinded by thoughts

driving us forward or backward,

consuming us.

Today we support each other

with small steps

focusing

cameras clicking

noticing

the lushness, muchness:
Correspondence

Dr. Jacobs

mljacobs@bu.edu

\section{MORE ONLINE}

\section{ค Audio}

Listen to Dr. Jacobs read this story.

NPub.org/2qheef 
fiery maples, click!

pink blossomed cherries, click!

overhead trellises

of limbs and leaves intertwined, click!

We visit the ancient tree,

made into a shrine,

one half acre canopy standing alone

after the church got converted

into condos.

We circumambulate

Fagus grandifolia

(a 150-year-old Copper beech), its thick roots above ground, growths bulging on its trunk, arms reaching into the ether.

We crane our necks

seeing patches of sky blue

through a crown

of red and green.

Smooth skin invites touch.

So we touch

our recovery mentor

strong, resilient, thriving

anchoring us

in the now and here reminding us

Everything changes.

After 20 minutes in Eden

we grow calm

practicing silence

meditation in nature

sparking hope

calming fear.

Seated back in the classroom

pens skate across paper

We move in silence

words untold unfold

until we hear

the bell of mindfulness

3 times ringing

waking us.

We share,

clap, praise

and without ego

rearrange

cut, replace words,

suggest line breaks,

empower verbs.

We are imagining

connecting, changing

starting anew. 


\title{
Neurology
}

\author{
Finding nature \& sanctuary in the city \\ Marjorie Jacobs \\ Neurology 2018;91;1105-1106 \\ DOI 10.1212/WNL.0000000000006657
}

This information is current as of December 10, 2018

\section{Updated Information \& Services}

Subspecialty Collections

Permissions \& Licensing

Reprints including high resolution figures, can be found at: http://n.neurology.org/content/91/24/1105.full

This article, along with others on similar topics, appears in the following collection(s):

\section{ADHD}

http://n.neurology.org/cgi/collection/adhd

All Psychiatric disorders

http://n.neurology.org/cgi/collection/all_psychiatric_disorders

All Rehabilitation

http://n.neurology.org/cgi/collection/all_rehabilitation Attention

http://n.neurology.org/cgi/collection/attention

Information about reproducing this article in parts (figures,tables) or in its entirety can be found online at:

http://www.neurology.org/about/about_the_journal\#permissions

Information about ordering reprints can be found online:

http://n.neurology.org/subscribers/advertise

Neurology ${ }^{\circledR}$ is the official journal of the American Academy of Neurology. Published continuously since 1951, it is now a weekly with 48 issues per year. Copyright (O 2018 American Academy of Neurology. All rights reserved. Print ISSN: 0028-3878. Online ISSN: 1526-632X.

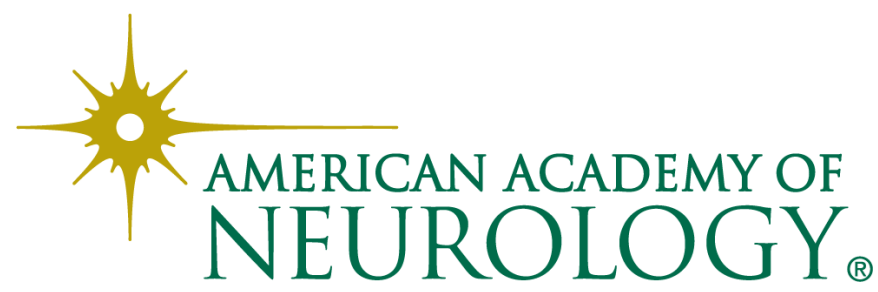

